\title{
Exploring Genotype by Environment Interaction in Winter Canola in North Carolina
}

\author{
Nicholas George (Corresponding author) \\ The North Carolina Solar Center, 1575 Varsity Drive \\ North Carolina State University, Raleigh, NC 27606, USA \\ \& \\ The Department of Horticultural Science, NC State University \\ 214 Kilgore Hall, Raleigh, NC 27695, USA \\ Tel: 1-919-452-8894 E-mail: Nicholas_George@ncsu.edu \\ Kim Tungate \\ The North Carolina Solar Center, 1575 Varsity Drive \\ North Carolina State University, Raleigh, NC 27606, USA \\ Cameron Beeck \\ School of Plant Biology, Faculty of Natural and Agricultural Sciences \\ The University of Western Australia, 35 Stirling Hwy., Crawley \\ WA 6009, and Canola Breeders Western Australia Pty Ltd \\ 15/219 Canning Hwy., South Perth, WA 6151, USA \\ Michael Stamm \\ Department of Agronomy, Kansas State University \\ 3702 Throckmorton Plant Sciences Center, Manhattan, KS 66506, USA
}

Received: May 5, $2011 \quad$ Accepted: May 25, $2011 \quad$ Online Published: December 21, 2011

doi:10.5539/jas.v4n2p237 URL: http://dx.doi.org/10.5539/jas.v4n2p237

This research was conducted under grants from the Golden Leaf Foundation and the North Carolina Small Grain Growers Association.

\begin{abstract}
Farmers in the Southeastern U.S have recently begun growing winter canola to meet a local demand for biodiesel, but optimal varieties for the region are unclear. Winter canola was trialed in North Carolina and the trial data analyzed to obtain estimates of genotype by environment interaction. Yields were found to be similar to the U.S. national average. There was considerable yield variation between varieties, with the minimum yield being 0.1 $\mathrm{Mg} / \mathrm{ha}$ and the maximum $3.4 \mathrm{Mg} / \mathrm{ha}$. Little genotype by environment interaction was observed. The low genotype by environment interaction indicates that the best performing cultivars are likely to be broadly adapted and that future evaluation can be reasonably restricted to a limited number of sites. The results suggest that if appropriate varieties are selected, winter canola could be an economically viable crop in the Southeastern U.S. It is recommended that winter canola varieties continue to be evaluated in the Southeast.
\end{abstract}

Keywords: Winter canola, Brassica napus, Southeastern United States, Genotype by environment interaction

\section{Introduction}

Annually, the United States produces over 500 thousand hectares of canola (Brassica napus L.) (NASS, 2010), primarily spring canola in North Dakota, with limited commercial production elsewhere (NASS, 2010). There has been long-standing interest in canola in the southeastern United States but a lack of local markets has acted 
as an obstacle to industry development. At current production costs and seed prices, winter canola can be economically viable, with a break-even yield of approximately $1.5 \mathrm{Mg} / \mathrm{ha}$ (George, Tungate, Hobbs, \& Atkinson, 2008). Farmers have therefore begun producing a small area of winter canola to meet the demand of the local biodiesel industry. However, growers in the region report mixed success from winter canola plantings.

Since 2000, winter canola has been evaluated in several states of the Southeastern U.S. as part of the Kansas State University Winter Canola Variety Trials. Data from these trials suggest that winter canola can perform well in the Southeast U.S. but, as would be expected, performance is strongly dependent on cultivar and year, with the top-performing varieties varying between sites and seasons. Analyses of genotype by environment interaction have been used to identify high-yielding and broadly-adapted canola genotypes (for example (Cullis, Smith, Beeck, \& Cowling, 2010; Gunasekera, Martin, Siddique, \& Walton, 2006; Javidfar, Alemkhomaram, Oghan, \& Azizinia, 2004; Marjanovic'-Jeromela, et al., 2011)) but to date there has been no attempt to conduct a similar analysis of data for winter canola from the Southeastern U.S. Furthermore, the authors continue to encounter Southeastern farmers who are unwilling to consider adopting canola due to perceived concerns regarding the potential for poor seedling establishment, low winter survival, lodging, and uneven maturity and shattering at harvest.

In this paper we report on the outcome of winter canola trials conducted in North Carolina. The trial data is analyzed to estimate genotype by environment interaction and evaluate the performance of cultivars on a state-wide basis. A general evaluation of the performance of canola in the context of the perceived problems with the crop in the Southeast is provided. The potential of canola in the state is assessed and recommendations regarding future research needs are made.

\section{Experimental}

\subsection{Site Description and Establishment}

Over three seasons, between 2007 and 2010, canola was established at seven trial sites North Carolina (Figure 1). All sites were located at research stations managed by either North Carolina States University or the North Carolina Department of Agricultural and Consumer Service: Clayton - Central Crops Research Station (35 4000 N 782900 W), Fletcher - Mountain Horticultural Crops Research Station (35 2400 N 823300 W), Jackson Springs - Sandhills Research Station (35 1100 N 794000 W), Oxford - Oxford Tobacco Research Station (36 1800 N 783600 W), Plymouth - Tidewater Research Station (35 5000 N 763900 W), Reidsville - Upper Piedmont Research Station (36 2200 N 794100 W), Williamsdale - Williamsdale Farm (34 4500 N 780600 W). Preliminary analysis of the data suggested that genotype by environment interaction was low, so the number of sites was reduced in the final season.

Site characteristics and agronomic information are given in Tables 1 and 2. Sites had a variety of edaphic characteristics. Soil analysis for each site was performed by the North Carolina Department of Agriculture and Consumer Services. Soil-type information for each site was obtained from the USDA Web Soil Survey (USDANRCS, 2010). The climatic conditions at each site were obtained from the State Climate Office of North Carolina (Table 3).

Throughout the study, sixty-five winter canola varieties were evaluated (Table 4). These varieties were selected from the National Winter Canola Variety Trial, which is coordinated by Kansas State University. The winter canola was planted approximately six weeks before the average date for the first killing frost $\left(-4^{\circ} \mathrm{C}\right)$ in the respective regions (late September in the western half of the state and early to mid October in the eastern half). Prior to planting, the sites were cultivated and treated with glyphosate for weed control. Seeding rates were approximately $5.5 \mathrm{~kg}$ per hectare using a 9-row grain drill with $15 \mathrm{~cm}$ row spacing. Individual plot dimensions were 1.2 by $5 \mathrm{~m}$ in the first year and 1.5 by $14.5 \mathrm{~m}$ in the two subsequent years. A $0.3 \mathrm{~m}$ alley between plots and a $0.6 \mathrm{~m}$ guard row were planted around the trial. The sites were rolled with a culti-paker before and after planting to provide a firm seedbed. Plots were arranged in a randomized complete block design with three replicates.

\subsection{Data Collection and Analysis}

Seedling emergence was recorded as plant numbers in two $0.5 \mathrm{~m}^{2}$ grids per plot. The peak flowering date was recorded as the date when approximately $50 \%$ of plots at a site were in flower. Varieties were harvested concurrently when the moisture content of a bulked seed sample taken from the guard row at a site was $10 \%$ or less (determined using a Superpro Moisture Analyzer and typically occurring in early- to mid-June). In the first year of the study, varieties were cut and threshed by hand. In subsequent years, a Gleaner R-76 small-plot combine was used. Flowering, lodging, shattering, and seedpod maturity were visually assessed using National Winter Canola Variety Trial protocols (Stamm, et al., 2010). 
Yield data was analyzed as a Multi-Environment Trial (MET) using the ASReml-R program (Gilmour, Cullis, Gogel, Welham, \& Thompson, 2005), which implements a factor analytic mixed model analysis adjusted for spatial field trends (A. Smith, Cullis, \& Gilmour, 2001). This type of analysis uses a two-stage approach, firstly, the data from individual trials from one year are analyzed using spatial techniques, then the variety-by-trial mean data is combined with data from all years for an overall mixed model analysis (A. Smith, Cullis, \& Gilmour, 2001; A. B. Smith, Cullis, \& Thompson, 2005). This produces an estimate of genotype, and genotype by environment interaction, providing a prediction of the yield of each variety at each environment and across different environments, as well as information about interactions with the environment (A. Smith, Cullis, \& Thompson, 2001). In the case of this dataset, a factor analytic model of order FA-1 explained $78 \%$ of the variance. For the clustering of environments, an agglomerative (nested) hierarchical clustering algorithm was used that is implemented in the "agnes" package of R (R Development Core Team 2009 (Cullis, et al., 2010)).

\section{Results}

The peak flowering date varied by site and year but generally occurred in the four-week period between the end of March and the end of April. Observations in late winter over all sites and years revealed close to $100 \%$ plant survival. Time to maturation was relatively uniform across all sites and years, and seed matured evenly. In the 2007-08 and 2009-2010 trials, all plots were at least 95\% mature at harvest, and in the 2008-2009 trial maturity was at least $85 \%$. Shattering was less than $15 \%$ and lodging was less than $5 \%$ across all sites and years.

There were few observations of pests and disease. Sclerotinia stem rot was observed at all the sites in the 2007-2008 season. Aphids were also observed on plants in 2007-008, however their occurrence was restricted to areas of only a few square meters and no damage was noted.

Over all sites and varieties, the average yield was $1.6 \mathrm{Mg} / \mathrm{ha}$. There was considerable variation in yield between varieties; across all sites, excluding Jackson Springs, the minimum yield was $0.1 \mathrm{Mg} / \mathrm{ha}$ (Jetton, Clayton 07-08) and the maximum $3.4 \mathrm{Mg} / \mathrm{ha}$ (Dimension, Williamsdale 08-09) (Table 4). The relative performance of the varieties, excluding Jackson Springs, is shown in Table 5. Varieties yielding in the top tenth percentile would be expected to achieve on average over $1.8 \mathrm{Mg} / \mathrm{ha}$ across all sites and seasons. The top varieties were $46 \mathrm{~W} 142.0$ $\mathrm{Mg} / \mathrm{ha}$, Dimension 2.0 Mg/ha, Kronos $2.0 \mathrm{mg} / \mathrm{ha}$, Baldur $1.9 \mathrm{Mg} / \mathrm{ha}$, Hybrisurf $1.8 \mathrm{Mg} / \mathrm{ha}$ and Visby $1.8 \mathrm{Mg} / \mathrm{ha}$.

The REML analysis showed all sites, with the exception of Jackson Springs, clustered together (Table 6). For this reason, Jackson Springs was excluded from the remainder of the analysis. Table 5 shows the individual performance of lines at each site over years as best linear unbiased predictions (BLUPs) plus the site mean. As the genetic correlations were high it is reasonable to average the BLUPS for all sites, except Jackson Springs, to get a ranking for lines at all sites in the MET (Table 6).

\section{Discussion}

This work found that the yield of winter canola in North Carolina compares favorably to the national average yield (1.6 Mg/ha) from commercial canola production in the United States (NASS, 2010). It should be noted, however, that much of the canola crop in the United States is spring canola, which would be expected to yield lower than winter canola. The mean yields achieved in this study are also comparable to those obtained in other states in the Southeast (Rife, 2002, 2004; Rife \& La Barge, 2005, 2006; Stamm \& La Barge, 2007, 2008; Stamm, et al., 2010; Stamm, La Barge, \& Roozeboom, 2006). Given current production costs and seed prices, this yield exceeds the minimum yield required for canola to be economically viable in the Southeast, and suggests winter canola should be competitive with winter wheat (Bullen \& Weddington, 2010), which is the other common winter crop option in the region.

Clustering in the REML analysis indicates that the ranking of winter canola genotypes in terms of yield across the sites is generally similar. The winter canola varieties in this experiment range from very un-adapted low-yielding material to broadly adapted high-yielding material and the results suggest that the rankings will likely be similar between sites as the un-adapted material will always be un-adapted, and low ranking, and the adapted material will be consistently better. Nevertheless, the high correlation between sites still suggests low genotype by environment interaction across the whole state, even with the diverse variety set in this study.

The finding of low genotype by environment interaction suggests that the best-performing varieties indentified in this study are also broadly adapted and suitable for production across the entire state. The top varieties were 46W14, Dimension, Kronos, Baldur, Hybrisurf and Visby. Given the broad adaption identified here it would be interesting to conduct a similar analysis using yield data from winter canola from other states in the Southeast US to explore the extent of this regional adaptation. The results also suggest that the future evaluation of winter canola in the state can be restricted to one or two sites in the Piedmont, thereby increasing the efficiency of the 
research efforts. However, if a market for winter canola in the region matures, and more varieties are developed, it is likely that the level of genotype by the environment interaction may increase as adaptation for particular environments improves. Under those circumstances, future evaluation of new germplasm on a more localized basis is advised.

The difference in variety ranking between Jackson Springs and the other sites is thought to be mainly associated with increased soil moisture at this site relative to the other sites. Jackson Springs received substantially more rainfall than the other sites and was also irrigated in spring, amounting to $25 \mathrm{~mm}$ per week through April. Additional soil moisture also resulted in increase mean yield across all varieties at the Jackson Springs site. The mean yield was $2.5 \mathrm{Mg} / \mathrm{ha}$, which is higher than the other sites, with the exception of Williamsdale in the 2008-2009 season, which achieved $2.8 \mathrm{Mg} / \mathrm{ha}$. We hypothesize that the high yield at Williamsdale was the result of high phosphorous indices at the site.

As the acceptable yield data indicates, across all the sites and years, the overall performance of winter canola in North Carolina was excellent. No problems were encountered in terms of pests and disease, poor seedling establishment or winter survival, lodging, or uneven maturity and shattering. Given our experience with winter canola in these trials, we believe that if farmers in the region adhere to recommended production guidelines perceived problems are unlikely to be encountered.

\section{Conclusions and Recommendations}

This research establishes that winter canola performs well in North Carolina. Mean yields are comparable to the national average and a number of varieties performed consistently above the mean, suggesting the potential for the commercialization of winter canola within the state given the development of suitable markets. Due to the promising results of this work, it is suggested that winter canola varieties continue to be evaluated in the Southeast region. Finally, given the low GxE detected for sites within North Carolina it would be interesting to conduct a MET analysis of data for study sites elsewhere the Southeast to determine the extent of this regional adaption.

\section{Acknowledgements}

We sincerely thank the faculty and staff of the NCSU Crop Science Department and the NCSU and NCDA\&CS Research Stations, for their support with this work. In particular, we wish to thank Doctors Ron Heiniger, Jim Green, Chris Reberg-Horton and Sue Ellen Johnson. Doctor Alex Hobbs and Chelsea Conover are thanked for providing project management support. Brad Faucette, John Palumbo, Andrew Smith, James Stahl and Will Haywood are thanked for providing technical help with field and laboratory work. Research funding was provided by the Golden LEAF Foundation and a generous donation from the North Carolina Small Grain Growers Association.

\section{References}

Bullen, G., \& Weddington, E. (2010). Wheat for grain conventional 2010 http://www.ag-econ.ncsu.edu/extension/wheatsoybean.html. Raleigh, North Carolina: North Carolina State Universityt. Department of Agricultural Economics.

Cullis, B. R., Smith, A. B., Beeck, C. P., \& Cowling, W. A. (2010). Analysis of yield and oil from a series of canola breeding trials. Part II. Exploring variety by environment interaction using factor analysis. Genome, 53(11), 1002. http://dx.doi.org/10.1139/G10-080

George, N., Tungate, K., Hobbs, A., \& Atkinson, A. (2008). The North Carolina Canola Production Guide. Raleigh, North Carolina: The North Carolina Solar Center, NC State University.

Gilmour, A. R., Cullis, B. R., Gogel, B. J., Welham, S. J., \& Thompson, R. (2005). ASReml user guide, release 2.0. Heml Hempstead, UK.: VSN Int.

Gunasekera, C. P., Martin, L. D., Siddique, K. H. M., \& Walton, G. H. (2006). Genotype by environment interactions of Indian mustard (Brassica juncea L.) and canola (B. napus L.) in Mediterranean-type environments 1. Crop growth and seed yield. European Journal of Agronomy, 25(1), 1-2. http://dx.doi.org/10.1016/j.eja.2005.08.002

Javidfar, F., Alemkhomaram, M. H., Oghan, H. A., \& Azizinia, S. (2004). Yield stability analysis of winter canola (Brassica napus L.) genotypes. Seed and Plant, 20(3), 315-328.

Marjanovic'-Jeromela, A., Terzic', S., Zoric', M., Marinkovic', R., Atlagic', J., Mitrovic', P., et al. (2011). Evaluation of seed and oil yield stability in NS rapeseed cultivars (Brassica napus L.). Ratarstvo i Povrtarstv, 48(1), 67-76. http://dx.doi.org/10.5937/ratpov1101067M 
NASS. (2010). National Agricultural Statistics Service (NASS): United States Department of Agriculture http://www.nass.usda.gov/

Rife, C. (2002). 2001 National Winter Canola Variety Trial. Manhattan, Kansas: Department of Agronomy, Kansas State University.

Rife, C. (2004). 2003 National Winter Canola Variety Trial. Manhattan, Kansas: Department of Agronomy, Kansas State University.

Rife, C., \& La Barge, C. (2005). 2004 National Winter Canola Variety Trial. Manhattan, Kansas: Department of Agronomy, Kansas State University.

Rife, C., \& La Barge, C. (2006). 2004 National Winter Canola Variety Trial Manhattan, Kansas: Kansas State University.

Smith, A., Cullis, B., \& Gilmour, A. (2001). The analysis of crop variety evaluation data in Australia. The Australian \& New Zealand Journal of Statistics, 43(2), 129-145.

Smith, A., Cullis, B., \& Thompson, R. (2001). Analyzing variety by environment data using multiplicative mixed models and adjustments for spatial field trends. Biometrics, 57, 1138-1147. http://dx.doi.org/10.1111/j.0006-341X.2001.01138.x

Smith, A. B., Cullis, B. R., \& Thompson, R. (2005). The analysis of crop cultivar breeding and evaluation trials: an overview of current mixed model approaches. The Journal of Agricultural Science, 143(6), 449-462. http://dx.doi.org/10.1017/S0021859605005587

Stamm, M., \& La Barge, C. (2007). 2006 National Winter Canola Variety Trial Manhattan, Kansas: Kansas State University.

Stamm, M., \& La Barge, C. (2008). 2007 National Winter Canola Variety Trial Manhattan, Kansas: Kansas State University.

Stamm, M., La Barge, C., Berrada, A., Bhardwaj, H., Caldbeck, B., Casteel, S., et al. (2010). 2009 National Winter Canola Variety Trial. Manhattan, KS.: Kansas Ag. Exp. St. and Coop. Ex. Ser. .

Stamm, M., La Barge, C., \& Roozeboom, K. (2006). 2005 national winter canola variety trial Manhattan, Kansas: Department of Agronomy, Kansas State University.

USDANRCS. (2010). Web Soil Survey http://websoilsurvey.nrcs.usda.gov/app/. from United States Department of Agriculture, Natural Resources Conservation Service (USDA NCRS).

Table 1. Details of soil analyses for the research sites

\begin{tabular}{|c|c|c|c|c|c|c|c|c|c|}
\hline 兽 & $\begin{array}{l}\tilde{0} \\
\text { ప్ } \\
\tilde{\aleph}\end{array}$ & 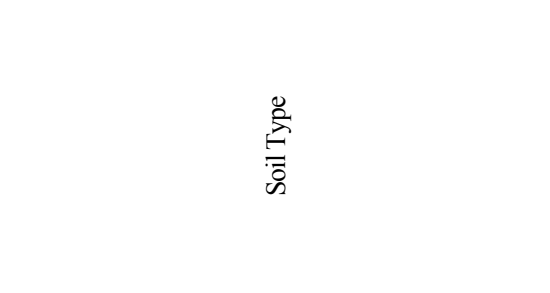 & 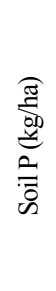 & 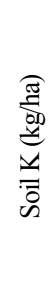 & 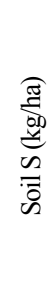 & 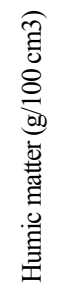 & 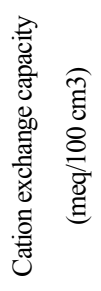 & $\frac{\bar{T}}{2}$ & 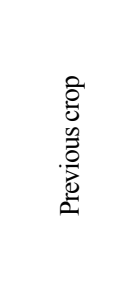 \\
\hline Clayton & $2007-2008$ & Wagram loamy sand & 96 & 254 & 28 & 0.46 & 2.9 & 5.8 & Small grain \\
\hline Fletcher & $2007-2008$ & Bradson gravelly loam & 170 & 375 & 39 & 0.41 & 7.3 & 6.1 & Fallow \\
\hline Jackson Springs & 2009-2010 & Candor Sand & 105 & 125 & 19 & 0.66 & 4.7 & 6.9 & Small grain \\
\hline Oxford & $2008-2009$ & Helena Sandy Loam & 201 & 176 & 44 & & 3.9 & 5.4 & Pasture \\
\hline Plymouth & $2007-2008$ & Portsmouth fine sandy loam & 151 & 352 & 99 & 4.95 & 11 & 4.7 & Potatoes \\
\hline Reidsville & $2007-2008$ & Rion sandy loam & 216 & 420 & 77 & 0.36 & 4.9 & 5.3 & Tobacco \\
\hline Reidsville & 2008-2009 & Rodhiss Sandy Loam & NA & NA & NA & NA & NA & NA & Pasture \\
\hline Willamsdale & $2008-2009$ & Goldsboro loamy Sand \& Noboco Loamy fine sand & 373 & 101 & 29 & 1.49 & 5.6 & 5.1 & Fallow \\
\hline Williamsdale & 2009-2010 & Goldsboro loamy Sand \& Noboco Loamy fine sand & 320 & 85 & 40 & 0.92 & 5.4 & 5.4 & Prairie grass \\
\hline
\end{tabular}


Table 2. Details regarding the management of the research sites

\begin{tabular}{|c|c|c|c|c|c|c|c|c|}
\hline & 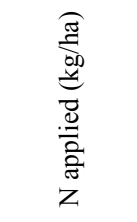 & 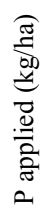 & 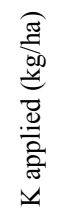 & & $\begin{array}{l}\vec{D} \\
\stackrel{0}{0} \\
\stackrel{0}{0} \\
\text { in }\end{array}$ & 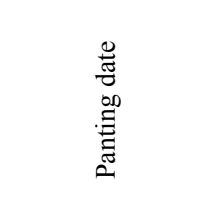 & 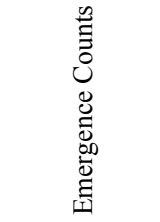 & 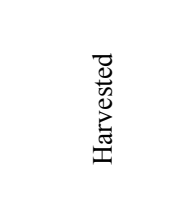 \\
\hline Clayton & $130-160$ & 55 & 170 & & $\mathrm{~L} / \mathrm{ha} 24 \mathrm{~S}$ & Oct 42007 & Dec 22007 & June 5-62008 \\
\hline Fletcher & $130-160$ & 0 & 0 & & 0 & Sept 202007 & Nov 242007 & June 19-20 2008 \\
\hline Jackson Springs & 30 and 90 & 50 & 0 & & $\mathrm{NH} 4 \mathrm{SO} 3$ & Oct 72009 & Nov 72009 & June 72010 \\
\hline Oxford & $100-110$ & 40 & 40 & & 0 & Oct 92008 & Nov 62008 & June 112009 \\
\hline Plymouth & $130-160$ & 0 & 0 & & 0 & Oct 112007 & Dec 122007 & June $16-172008$ \\
\hline Reidsville & $130-160$ & 0 & 0 & & 0 & Sept 252007 & Nov 212007 & June $11-122008$ \\
\hline Reidsville & 130 & 0 & 0 & & 30 & Oct 82008 & Nov 52008 & Jun 192009 \\
\hline Willamsdale & 30 and 90 & 0 & 0 & 26 & NH4SO3 & October 202009 & Nov 172009 & June 82010 \\
\hline Williamsdale & 30 and 90 & 0 & 0 & 26 & NH4SO3 & Oct 102008 & Nov 42008 & June 42009 \\
\hline
\end{tabular}

Table 3. Climatic conditions reported for each site throughout the study

\begin{tabular}{|c|c|c|c|c|c|}
\hline & Ave $\left({ }^{\circ} \mathrm{C}\right)$ & Max $\left({ }^{\circ} \mathrm{C}\right)$ & $\operatorname{Min}\left({ }^{\circ} \mathrm{C}\right)$ & $\begin{array}{c}\text { Rain and irrigation } \\
(\mathrm{mm})\end{array}$ & Year \\
\hline Clayton & 12.6 & 29.6 & -4.1 & 504 & $2007-2008$ \\
\hline Fletcher & 10.2 & 25.1 & -7.9 & 640 & $2007-2008$ \\
\hline Jackson Springs & 11.7 & 26.6 & -4.2 & 1294 & $2009-2010$ \\
\hline Oxford & 10.7 & 25.3 & -8.2 & 725 & $2008-2009$ \\
\hline Plymouth & 12.9 & 30.8 & -3.3 & 495 & $2007-2008$ \\
\hline Reidsville & 11.9 & 29.3 & -4.7 & 499 & $2007-2008$ \\
\hline Reidsville & 10.7 & 26.6 & -8.4 & 733 & $2008-2009$ \\
\hline Williamsdale & 12.1 & 26.9 & -4.2 & 555 & $2008-2009$ \\
\hline Williamsdale & 13.9 & 28.5 & -3.6 & 429 & $2009-2010$ \\
\hline
\end{tabular}


Table 4. The estimated per hectare yield of the winter canola varieties at various sites in North Carolina ( $\mathrm{Mg} / \mathrm{ha})$

\begin{tabular}{|c|c|c|c|c|c|c|c|c|c|}
\hline ENTRY & $\begin{array}{c}\text { Clayton } \\
07-08 \\
\end{array}$ & $\begin{array}{c}\text { Fletcher } \\
07-08 \\
\end{array}$ & $\begin{array}{c}\text { Plymouth } \\
07-08\end{array}$ & $\begin{array}{c}\text { Reidsville } \\
07-08\end{array}$ & $\begin{array}{c}\text { Oxford } \\
08-09\end{array}$ & $\begin{array}{c}\text { Williams } \\
08-09 \\
\end{array}$ & $\begin{array}{c}\text { Reidsville } \\
08-09\end{array}$ & $\begin{array}{c}\text { Williams } \\
09-10 \\
\end{array}$ & $\begin{array}{c}\text { Jackson Springs } \\
09-10 \\
\end{array}$ \\
\hline $45 \mathrm{D} 03$ & 0.75 & 1.64 & 1.24 & 1.47 & & & & & \\
\hline $46 \mathrm{~W} 14$ & 1.47 & 1.92 & 2.04 & 1.82 & 1.74 & 3.2 & 1.88 & & \\
\hline 46W99 & 1.21 & 1.7 & 1.61 & 1.65 & & & & & \\
\hline ARC00005-2 & & & & & & & & 2.09 & 2.45 \\
\hline ARC00024-2 & & & & & & & & 2.1 & 2.45 \\
\hline ARC2180-1 & 1.05 & 1.69 & 1.49 & 1.68 & & & & & \\
\hline ARC2189-2 & & & & & & & & 2.13 & 2.44 \\
\hline ARC98015 & 1 & 1.74 & 1.51 & 1.73 & & & & & \\
\hline ARC99009-1 & & & & & & & & 2.12 & 2.44 \\
\hline Baldur & 1.21 & 1.77 & 1.75 & 1.81 & 1.56 & 2.98 & 1.85 & 2.19 & 2.41 \\
\hline Ceres & 1.09 & 1.65 & 1.45 & 1.64 & & & & & \\
\hline CWH081 & 1 & 1.71 & 1.52 & 1.62 & & & & & \\
\hline CWH095 & 1.21 & 1.78 & 1.66 & 1.62 & & & & & \\
\hline CWH111 & 0.97 & 1.8 & 1.53 & 1.54 & 1.49 & 2.76 & 1.83 & & \\
\hline CWH116 & 0.64 & 1.42 & 1.08 & 1.28 & & & & & \\
\hline CWH633 & 0.84 & 1.77 & 1.35 & 1.55 & & & & & \\
\hline Dimension & 1.37 & 1.85 & 1.93 & 1.8 & 1.6 & 3.4 & 1.86 & 2.23 & 2.4 \\
\hline DKW13-69 & 0.84 & 1.66 & 1.22 & 1.37 & & & & & \\
\hline DKW41-10 & 0.93 & 1.49 & 1.33 & 1.51 & & & & & \\
\hline DKW45-10 & 0.84 & 1.58 & 1.32 & 1.61 & & & & & \\
\hline DKW46-15 & 0.95 & 1.55 & 1.29 & 1.55 & & & & & \\
\hline DKW47-15 & 0.99 & 1.8 & 1.45 & 1.42 & & & & & \\
\hline DSV07100 & 1.3 & 1.99 & 1.78 & 1.82 & & & & & \\
\hline Dynastie & & & & & & & & 2.05 & 2.47 \\
\hline Flash & 0.67 & 1.39 & 1.12 & 1.15 & & & & 1.96 & 2.49 \\
\hline Forza & 1.24 & 1.75 & 1.77 & 1.7 & & & & & \\
\hline Hornet & 0.57 & 1.33 & 1.01 & 1.01 & & & & & \\
\hline HPX-501 & 0.64 & 1.42 & 0.96 & 1.18 & & & & & \\
\hline HPX-567 & 0.7 & 1.56 & 1.16 & 1.33 & & & & & \\
\hline Hybrigold & 1.23 & 1.91 & 1.78 & 1.7 & 1.36 & 2.6 & 1.81 & & \\
\hline Hybristar & 1.05 & 1.75 & 1.49 & 1.49 & 1.44 & 3 & 1.83 & 2.14 & 2.44 \\
\hline Hybrisurf & 1.14 & 1.72 & 1.54 & 1.65 & 1.58 & 2.93 & 1.84 & 2.17 & 2.42 \\
\hline HyClass107W & 0.7 & 1.47 & 1.1 & 1.38 & & & & & \\
\hline HyClass110W & 1.05 & 1.64 & 1.58 & 1.76 & 1.41 & 2.67 & 1.82 & & \\
\hline HyClass $115 \mathrm{~W}$ & 0.93 & 1.7 & 1.44 & 1.51 & & & & & \\
\hline HyClass154W & 0.86 & 1.75 & 1.51 & 1.52 & 1.2 & 2.43 & 1.79 & 1.99 & 2.49 \\
\hline Jetton & 0.13 & 1.05 & 0.39 & 0.79 & & & & & \\
\hline Kadore & 0.94 & 1.83 & 1.39 & 1.51 & 1.42 & 2.93 & 1.82 & 2.09 & 2.45 \\
\hline Kiowa & 1 & 1.74 & 1.45 & 1.61 & 1.43 & 2.7 & 1.82 & & \\
\hline Kronos & 1.42 & 2.04 & 1.92 & 1.81 & 1.65 & 2.97 & 1.87 & & \\
\hline KS3018 & 0.84 & 1.61 & 1.33 & 1.43 & & & & & \\
\hline KS3074 & 1.06 & 1.73 & 1.56 & 1.62 & & & & & \\
\hline KS3077 & 1.01 & 1.92 & 1.51 & 1.57 & 1.57 & 2.62 & 1.83 & & \\
\hline KS3132 & 0.93 & 1.73 & 1.36 & 1.49 & & & & & \\
\hline KS3254 & 0.89 & 1.72 & 1.42 & 1.55 & & & & & \\
\hline KS3302 & 1.1 & 1.83 & 1.6 & 1.56 & 1.43 & 2.98 & 1.84 & & \\
\hline KS4022 & 0.85 & 1.58 & 1.37 & 1.44 & & & & & \\
\hline KS4085 & 0.82 & 1.66 & 1.18 & 1.4 & & & & & \\
\hline Rally & 0.55 & 1.41 & 0.97 & 1.14 & & & & & \\
\hline Rapeseed & 0.73 & 1.51 & 1.26 & 1.37 & & & & & \\
\hline Riley & 1.02 & 1.68 & 1.51 & 1.6 & 1.41 & 2.67 & 1.83 & & \\
\hline Safran & 0.77 & 1.46 & 1.23 & 1.33 & & & & 2.03 & 2.47 \\
\hline Satori & 1.07 & 1.66 & 1.48 & 1.59 & & & & & \\
\hline Sitro & 0.79 & 1.4 & 1.17 & 1.21 & & & & 2.06 & 2.48 \\
\hline Sumner & 0.88 & 1.55 & 1.28 & 1.55 & & & & & \\
\hline Taurus & 1.18 & 1.69 & 1.72 & 1.87 & & & & & \\
\hline Virginia & 0.92 & 1.66 & 1.42 & 1.48 & 1.47 & 2.98 & 1.82 & & \\
\hline Visby & 0.98 & 1.81 & 1.53 & 1.6 & 1.56 & 2.77 & 1.83 & 2.18 & 2.43 \\
\hline Wichita & 0.91 & 1.65 & 1.46 & 1.55 & 1.31 & 2.56 & 1.82 & 2.18 & 2.43 \\
\hline
\end{tabular}


Table 5. Overall rank of BLUPS as deviations from the mean $(1.6 \mathrm{Mg} / \mathrm{ha})$ for 8 sites tested over 3 years

\begin{tabular}{|c|c|c|c|}
\hline Variety & Rank & Variety & Rank \\
\hline $46 \mathrm{~W} 14$ & 0.35 & Virginia & 0.01 \\
\hline Kronos & 0.3 & Arc00024-2 & 0 \\
\hline NPZ0791RR & 0.25 & HyClass115W & 0 \\
\hline Dimension & 0.24 & KS3254 & -0.01 \\
\hline DSV07100 & 0.24 & Arc00005-2 & -0.02 \\
\hline Forza & 0.19 & HyClass110W & -0.02 \\
\hline Baldur & 0.18 & KS3132 & -0.02 \\
\hline Taurus & 0.17 & Wichita & -0.02 \\
\hline CWH095 & 0.15 & DKW41-10 & -0.04 \\
\hline Hybrisurf & 0.14 & DKW46-15 & -0.04 \\
\hline $46 \mathrm{~W} 99$ & 0.13 & CWH633 & -0.04 \\
\hline Hybrisurf & 0.1 & DKW45-10 & -0.05 \\
\hline KS3302 & 0.1 & Hybrigold & -0.05 \\
\hline HyClass117W & 0.09 & KS4022 & -0.05 \\
\hline KS3074 & 0.08 & KS3018 & -0.06 \\
\hline Visby & 0.07 & Sumner & -0.06 \\
\hline ARC2180-1 & 0.06 & Dynastie & -0.07 \\
\hline ARC2189-2 & 0.06 & DKW13-69 & -0.09 \\
\hline ARC98015 & 0.06 & 45D03 & -0.1 \\
\hline KS3077 & 0.06 & Safran & -0.1 \\
\hline Ceres & 0.05 & KS4085 & -0.11 \\
\hline CWH081 & 0.05 & Rapeseed & -0.12 \\
\hline CWH111 & 0.05 & Sitro & -0.15 \\
\hline Hybristar & 0.05 & HPX-567 & -0.16 \\
\hline Satori & 0.05 & HyClass107W & -0.17 \\
\hline Riley & 0.04 & CWH116 & -0.21 \\
\hline ARC99009-1 & 0.03 & Flash & -0.21 \\
\hline Kiowa & 0.03 & HPX-501 & -0.25 \\
\hline DKW47-15 & 0.02 & Hornet & -0.27 \\
\hline HyClass154W & 0.01 & Rally & -0.27 \\
\hline Kadore & 0.01 & Jetton & -0.59 \\
\hline
\end{tabular}

Table 6. The genetic correlation between sites for canola yield tested in North Carolina

\begin{tabular}{|c|c|c|c|c|c|c|c|c|c|}
\hline & 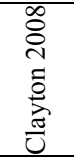 & $\frac{\vec{D}}{\stackrel{0}{0}} \stackrel{\infty}{0}$ & 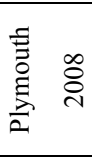 & $\begin{array}{l}\stackrel{0}{=} \\
\stackrel{0}{*} \\
\stackrel{0}{0} \\
\stackrel{0}{\simeq}\end{array}$ & 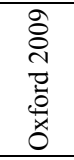 & 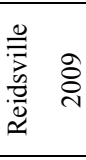 & 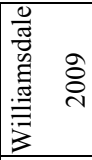 & 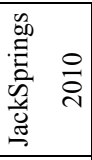 & 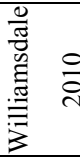 \\
\hline Clayton 2008 & 1.00 & & & & & & & & \\
\hline Fletcher 2008 & 0.71 & 1.00 & & & & & & & \\
\hline Plymouth 2008 & 0.90 & 0.71 & 1.00 & & & & & & \\
\hline Reidsville 2008 & 0.78 & 0.62 & 0.79 & 1.00 & & & & & \\
\hline Oxford 2009 & 0.80 & 0.64 & 0.81 & 0.70 & 1.00 & & & & \\
\hline Reidsville 2009 & 0.94 & 0.75 & 0.95 & 0.83 & 0.85 & 1.00 & & & \\
\hline Williamsdale 2009 & 0.69 & 0.55 & 0.70 & 0.61 & 0.62 & 0.73 & 1.00 & & \\
\hline JackSprings 2010 & -0.94 & -0.75 & -0.95 & -0.83 & -0.85 & -1.00 & -0.73 & 1.00 & \\
\hline Williamsdale 2010 & 0.80 & 0.64 & 0.81 & 0.71 & 0.72 & 0.85 & 0.63 & -0.85 & 1.00 \\
\hline
\end{tabular}

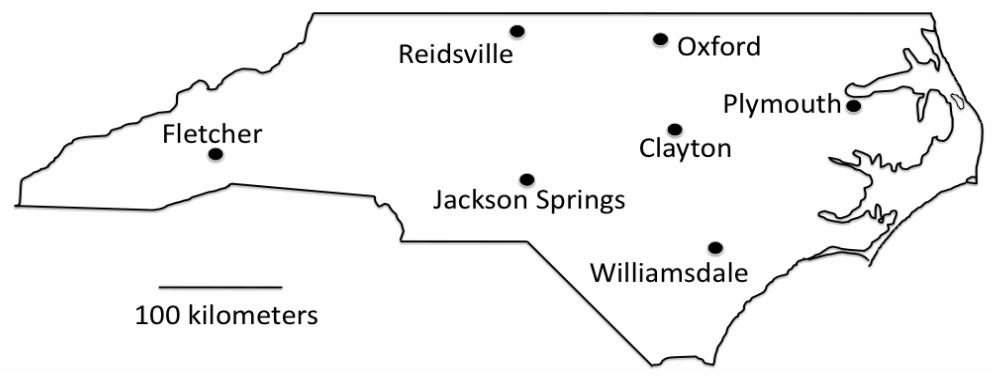

Figure 1. The location of winter canola variety trial sites in North Carolina between 2007 and 2010 